\title{
Providing a simple online toolkit for school libraries in developing countries so that they can become centers of competence in primary and secondary schools
}

\author{
Helen Boelens \\ ENSIL Foundation, The Netherlands. \\ Henk van Dam \\ Senior Project Officer, Royal Tropical Institute, KIT Information \& Library Services, \\ Amsterdam, The Netherlands.
}

\begin{abstract}
This paper describes a co-operative effort between the ENSIL Foundation and the Royal Tropical Institute, KIT Information and Library Services to provide school libraries, especially those in developing countries, with a simple online toolkit, which will help them to become centres of competence in primary and secondary schools. It is based on a similar toolkit which was designed by the KIT and is being used by university libraries throughout Africa.

Although many school libraries have few facilities or funding, the IFLA/FAIFE World Report 2010 reports that approximately 30\% of all school libraries worldwide now have Internet access. Using free open access software, the toolkit will provide school libraries with simple (online) training opportunities for library staff in literacy and information literacy skills, an advocacy platform, simple cataloguing tools, and access to online (full-text) resources). In addition it will provide access to online communities which focus on knowledge sharing.

The paper will also broach the subject of an international, online, open-access repository for school libraries.
\end{abstract}

\section{Introduction}

A modern library is both a function and a learning venue. One of its tasks is to use both modern technology and traditional tools to improve literacy skills and educational quality. In 2011 the Royal Tropical Institute - KIT Information \& Library Services - in Amsterdam, the Netherlands developed an Institutional Repository Online Toolkit promoting Free and Open Source Software (FOSS) for African academic libraries (Institutional Repository Communication Platform, 2013). It is currently being used and evaluated at number of African universities.

Due to the increasing availability of Internet services in school libraries throughout the world (Bothma, 2007 and 2011), discussions are now taking place with KIT, the ENSIL Foundation, the IASL and other organizations and charities, to try to determine whether or not the toolkit for university libraries can be adjusted for use as a universal toolkit for multicultural school libraries, especially those in developing and emerging countries. Its application would facilitate school library development. 


\section{Background Information}

For the first time in 2007, and again in 2010, the IFLA/FAIFE World Report approached National Libraries, National Library Associations and other library organisations throughout the world and asked them to answer some questions about libraries (including school libraries) in their own countries. 129 countries provided statistics about the existence of school libraries. Six other countries reported that they have school libraries but that statistics were unavailable (Bothma, 2007 and 2011). More than 908,000 school libraries, serving more than 540 million children were reported. It should be noted that details of school libraries in some countries were not reported to the IFLA/FAIFE World Reports 2007 and 2010 because reliable data at national level was unavailable (Bothma, 2007 and 2011).

Also, the 2010 Report confirmed an increasing availability of Internet in school libraries and confirmed that $30 \%$ of these school libraries now have internet access. This percentage in increasing rapidly (Bothma, 2011). This increasing access to Internet and mobile technology in school libraries throughout the world makes the application of an international online school library toolkit possible in some schools.

\section{What is a School Library? - an International Definition}

How can the school libraries mentioned above Bothma (2007 and 2011) be defined? Images and concepts of the function of a school library vary from country to country. School libraries throughout the world come in many different shapes and sizes. Research has shown that some "school libraries" are actually a box of dirty old books in the corner of the school (Boelens, 2010). Some schools do not have a room or special space for the library. Also, people who run libraries are often teachers, parents, volunteers and sometimes the children themselves, who have received various levels of (or virtually no) training in library and information science.

An international school library toolkit would provide instruments and services for school libraries throughout the world and should be appropriate for (full or partial) usage in many different learning situations. It must therefore rely on an international definition of what a school library actually is. It should be possible to apply this definition to school libraries in developing, emerging and developed countries, in all the IASL world regions.

Team members of the IASL Research SIG agree that an appropriate definition for a school library at international level is essential before meaningful international research about school libraries can be carried out. This important subject is currently being discussed by them in detail and results of these discussions will be published at a later date. However, at a meeting in Lisbon on 25 May 2012, which was attended by some SIG members, and representatives of the Ministry of Education and the School Library Association of Portugal, it was agreed that an incomplete definition would at least contain some of the following aspects:

- The school library provides a service to the school and supports learning and teaching for the entire school community;

- This service provides expertise in two different disciplines: Education and Library and Information Science (LIS);

- It offers advice, professional development and knowledge of appropriate learning and teaching materials, digital and non-digital (Phillips, 2011);

- School libraries are run / managed by school librarians / teacher librarians who have been educated to carry out this work and have received an applicable 
accreditation;

- The most important resource services are the human resources. Teacher librarians contribute to quality teaching and authentic learning (Phillips, 2011);

- One of the functions of the school library is to teach learners media and information literacy skills.

- The promotion of literacy and the love of reading is perhaps the school library's most important function.

Attendees at the Lisbon meeting agreed to submit further suggestions on this subject to the IASL Research SIG.

\section{Objectives of the International School Library Toolkit}

The objectives of an international school library toolkit are as follows:

Literacy, education and learning outcomes Throughout the world there are cultural groups which have no reading culture. In some cases, their mother tongue is not even been written down. These people have no (or very few) books in their homes, supplies of reading materials at schools are often inadequate and public libraries are few and far between. The World Bank (2011) and UNICEF, Childinfo organisation (2010) report that there is an increase in (primary) school attendance in different developing countries, especially throughout the African continent, necessitating the development of good school libraries for children who are now able to attend school. Furthermore, worldwide statics relating to literacy (UNICEF, 2010; World Bank, UNESCO UIS, 2011) show the urgent need to provide facilities so that children could improve their literacy skills and thus improve their learning outcomes.

The region of South and West Asia is home to more than one-half of the global illiterate population (51.8\%). In addition, $21.4 \%$ of all illiterate adults live in subSaharan Africa, 12.8\% in East Asia and the Pacific, 7.6\% in the Arab States and 4.6\% in Latin America and the Caribbean. Less than 2\% of the global illiterate population lives in North America and Western Europe, Central and Eastern Europe, and Central Asia combined. ... (UNESCO UIS, 2011)

For this reason, the primary objective of an international school library toolkit is literacy and an increase in learning outcomes - to increase technical reading, comprehension, information literacy skills (educational quality), reading pleasure and affinity with books for children from 4 to 18 years. The toolkit will also disseminate education-related data in easy-to-understand ways to a variety of audiences.

School library advocacy School libraries are essential to the development of literacy and to the improvement of learning outcomes. Appropriate resources and training materials for international school library advocacy can be made available through the school library toolkit and in the online repository which is one of the modules in the toolkit. Some forms of advocacy are also mentioned below (see Communication).

Online library facilities Amenities such as free online access to a variety of (full text) national and international content (e.g. databases, research data, curricula, learning materials, 
books, journals, videos, tutorials, presentations, photographs, magazines, news clippings) will be provided. By building on an existing infrastructure, while at the same time tapping into recent innovations through strategic partnerships, the project will be able to introduce local innovation in a truly sustainable manner.

Training While draft definitions for a school library at international level (above) contain clear indications that a school library should be run by a school librarian or teacher librarian who is accredited at tertiary level, many school libraries throughout the world are still run by teachers, volunteers and pupils who have no training in library and information science or in pedagogy. In fact, training in library and information science at tertiary level may not be available at accredited national universities in some countries. The toolkit will offer essential training in library and information science (LIS), media and information literacy and ICT skills. School library staff will be encouraged to follow these (free) modules so that the quality of the school library will gradually increase.. At the same time, national governments and school leaders will be encouraged to eventually provide tertiary level education and accreditation for school library staff.

The proposed toolkit will contain modules for the professional development of school library staff, teachers and pupils, such as:

- Library and Information (LIS) skills;

- Media and Information Literacy skills;

- ICT skills,

as described below. In turn, librarians and teachers will pass these skills on to the rest of the school community. Furthermore, the toolkit will also provide data and information to improve teacher preparation.

Assessment The toolkit will contain assessment modules which will allow teachers and education officials to make rapid and efficient student assessments. Modules for teacher evaluations and data to support the development of appropriate incentive systems for teachers and officials will also be provided. These will be based on teacher performance and student results.

Communication The toolkit will provide a module for training in the usage of online communities / forums / social media focusing on knowledge sharing. The provision of a platform to publicize the need for "A Library in Every School" is very important. Library staff should receive training in the use of online communication tools, so that different school libraries can help each other. KIT has already provided a portal and Facebook page "Librarianship in the South" - for this purpose. School librarians throughout the world are encouraged to use these facilities and to send information to them for publication.

\section{Modules for the International School Library Toolkit}

The school library toolkit will provide step-by-step checklists for many library and learning processes, from simple electronic cataloguing or the acquisition of books (traditional and online) to a sophisticated monitoring \& evaluation system to measure the impact of information or the mainstreaming of online communities in learning. Emphasis is placed on improving (traditional and digital) collections and facilities in a school library, and providing simple training for the students, teachers and librarians who use it. The tool can be used in 
any stage of development of a library, and combines mobile technology with the traditional concept of a school library. Initially the toolkit will be developed in Portuguese, English and French and is expected to be piloted in three countries (Mozambique, Ghana, and DR Congo) representing these three major language groups.

The international school library toolkit is expected to contain the following modules:

- Toolkit Plan of Action: needs assessment and drafting an information plan, setting up a library;

- School library advocacy;

- Budgeting;

- Registration and Cataloguing;

- Acquisition of books;

- Copyright issues;

- Online Public Catalogue (OPC);

- Indexing/ tagging;

- Preservation and conservation;

- Searching Internet and Databases;

- Online publishing (Repository);

- Website and Intranet;

- Media and Information Literacy;

- Knowledge sharing, online communities;

- Library management;

- ICT and Library; School library facilities and requirements;

- Mobile Technology and the library;

- Social Media and the Library;

- Measuring impact of Information/ M\&E;

\section{Services Provided by the Toolkit}

The international school library toolkit will provide the following additional services:

- multilingual, multicultural open access materials and resources;

- suggestions for multilingual, multicultural collection development;

- open access cataloguing tools;

- additional training programs for school library staff; training webinars, etc.

- additional media and information literacy instruction,

- multilingual online communication tools, using social networking, internet portals, providing support to librarians.

\section{Funding}

A provisional budget includes the development of the toolkit, establishment of libraries where necessary and the implementation of pilots in 3 pilot countries (in 10 school libraries per country). At this point, funding for the development of this school library toolkit is a problem; different organizations and charities are being approached and being asked to provide financial assistance.

It is important to note that the existence of a university library is one of the international criteria for university accreditation and therefore funding became available from international organizations to support the development of a toolkit for these libraries. This 
type of funding was used by KIT in the development of the toolkit for university libraries. Obtaining funding for an international school library toolkit is more difficult.

\section{Plan of Action}

A plan of action ( module 1 in the toolkit) has been prepared. The development of the international school library toolkit is expected to take place as follows after sufficient funding becomes available, as follows:

- Meeting of stakeholders (members of the consortium);

- Contact with school libraries (initially in countries where pilots will take place Mozambique, Ghana and DR Congo - 10 school libraries in each country);

- Development and adjustment of existing modules.

- Training (all modules - both online and onsite instructions)

- Provision of the services mentioned above.

- Development of an on-site library or reading room, where necessary.

\section{Conclusions}

An international online school library toolkit would increase the quality of school libraries worldwide and would result in an increase in educational quality and academic achievement. While the need for and objectives of a toolkit are clear, action on the development of the toolkit, as outlined above, can only begin after the necessary funding becomes available. At this point, various organizations and charitable organisations have been approached with requests for assistance.

\section{References}

Boelens, H. (2010) The evolving role of the school library and information centre in education in digital Europe. London : Middlesex University, School of Arts and Education. Accessed on 24 November, 2011: http://eprints.mdx.ac.uk/7329/

Bothma, T. J. (ed.) (2007) IFLA/FAIFE World Report Series, Vol. VII, IFLA World Report 2007. Accessed on May 30, 2012, from IFLA (International Federation of Library Associations and Institutions): http://www.ifla.org/en/faife/the-world-report-2007-toc

Bothma, T. J. (ed.) (2011) IFLA/FAIFE World Report Series, Vol. VIII, IFLA World Report 2010. Accessed on September 30, 2011, from IFLA (International Federation of Library Associations and Institutions):

http://www.ifla-world-report.org/files/uploaded/ifla wr/IFLA-WR-2010-Analysisand-Conclusions.pdf

Dam, H. van, T. Madzija, A. Martinho, R. Waete (2010) Knowledge, attitudes and practices with respect to institutional repositories in Mozambique: a benchmark study Royal Tropical Insitute (KIT) Amsterdam http://www.search4dev.nl/document/207883

Dam, H. van (2011) SABER: an innovative approach to creating a FOSS (DSpace) Open Access Repository, eIFL, Maputo, June 2011: http://www.eifl.net/saber-unique-andinnovative-foss-open-access-repos

Institutional Repository Communication Platform (2013). Open Access Repositories: 
Capacity Strengthening Programme for Africa (OA - IRCSP) http://www.irafrica.info/ accessed on 31 May 2012.

Phillips, Georgia (2011) A School Library Service declaration. The Hub, Australia, national campaign to promote quality school libraries in Australia:

http://www.gopetition.com/petitions/school-library-service-declaration.html

UNESCO Institute for Statistics. (2011, September). Adult and Youth Literacy, Factsheets, September 2011, No. 16. Accessed on September 30, 2011, from UNESCO Institute for Statistics (UIS): http://www.uis.unesco.org/FactSheets/Documents/FS16-2011Literacy-EN.pdf

UNICEF (2010). Child Info : Monitoring the situation of children and women : Statistics by area : Education. Accessed on September 30, 2011, from Child Information Organisation: http://www.childinfo.org/education primary.php

The World Bank. (2011). The World Bank, Education Statistics. Accessed on September 30, 2011, from The World Bank: http://web.worldbank.org/WBSITE/EXTERNAL/TOPICS/EXTEDUCATION/EXTD ATASTATISTICS/EXTEDSTATS/0,,menuPK:3232818 pagePK:64168427 piPK:64 168435 theSitePK:3232764,00.html 